J. Clin. Chem. Clin. Biochem.

Vol. 26, 1988, pp. 689-691

(C) 1988 Walter de Gruyter \& Co.

Berlin - New York

\title{
Measurement of Liver Iron Content in Paraffin-Embedded Biopsies
}

\author{
By C. van Deursen
}

Department of Internal Medicine

M. de Metz

Department of Clinical Chemistry

\section{J. Koudstaal}

Department of Pathology and

\section{P. Brombacher}

Department of Clinical Chemistry

De Wever-Hospital, Heerlen, The Netherlands

(Received July 20, 1988)

Summary: A reliable method for the determination of total liver iron in formalin-fixed, paraffin-embedded tissue is presented. The correlation with total liver iron in fresh tissue is good $(r=0.92)$.

Material, which is processed routinely in the pathological anatomical department and stored in the archives, can be used for a quantitative iron determination for clinical or research purposes.

\section{Introduction}

Several indirect methods are available for estimating the liver iron content, e.g. serum ferritin concentration, transferrin saturation and desferrioxamine-chelatable iron (1).

Direct methods can be divided into two groups: chemical measurement of iron concentration (2) and histological grading of stainable iron (3). The correlation between these two direct methods is not always good (4), and the evaluation of indirect methods is therefore cumbersome. These differences might partly be explained by the different techniques used for histology and chemistry, but it is clear that sampling effects, especially in pathological situations, has to be taken into account. Pathology might be detected in one biopsy, and undetected in a second biopsy of the same liver. A recent paper recommends three biopsies to avoid this problem (5). As the clinical chemistry department and the pathological anatomical department usually receive different biopsies, discrepancies between chemical and histological determination of iron content can be expected with inhomogeneous liver tissue. These discrepancies can be minimized by using the same biopsy. Furthermore, because the need for a chemical determination of iron is not always foreseeable and will sometimes only be wanted after histochemical examination, it would also be advantageous if the material from a pathological anatomical department were available for chemical iron analysis. We recently introduced a method for the measurement of liver iron with flameless atomic absorption spectroscopy, which has a low coefficient of variation. 
The homogenized liver tissue is strained to remove non-homogenized material (bile ducts, collageneous tissue, vessel walls) and the iron content is expressed per $\mathrm{mg}$ homogenized protein (6). In this paper we describe a further development of the method for the measurement of iron in paraffin-embedded, fixed liver tissue, which enables a chemical determination of total iron in material routinely processed for histological examination.

\section{Materials and Methods}

\section{Liver tissue and sample preparation}

Liver biopsies were taken percutaneously with a Tru-cut needle. Fresh human liver tissue was obtained from 60 consecutive autopsies. From the right and left lobe of the liver two pieces of tissue were removed (size about $1 / 2 \times 1 / 2 \times 1 \mathrm{~cm}$ ). One piece was fixed in formaldehyde $40 \mathrm{~g} / \mathrm{l}$ and embedded in paraffin as usual for routine histological processing. The other piece of liver tissue was stored at $-80^{\circ} \mathrm{C}$. Small pieces of thawed material $(\leqslant 10 \mathrm{mg})$ or biopsies $(\leqslant 5 \mathrm{mg}$ ) were washed three times with $15 \mathrm{ml}$ ice cold $150 \mathrm{mmol} / 1 \mathrm{NaCl}$ for $5 \mathrm{~min}$. The washed liver tissue was homogenized in $200 \mu \mathrm{l} 150 \mathrm{mmol} / \mathrm{l}$ $\mathrm{NaCl}$ per $10 \mathrm{mg}$ tissue in a glass homogenizer by 20 strokes with a loose fitting pestle. The homogenate was strained through a glass sintered filter to remove non-homogenized material.

Paraffin-embedded liver tissue (0.1-1.0 mg protein) was washed with $n$-hexane to remove the paraffin. After drying, the liver sample was homogenized as described above, or weighed and digested at $90^{\circ} \mathrm{C}$ for $2 \mathrm{~h}$ with a mixture of sulphuric acid/ nitric acid $(1+1$ by vol.).

\section{Methods and reagents}

Flameless atomic absorption spectrophotometry was performed as described previously (7). Protein was measured according to Lowry et al. (8) with bovine serum as a standard. All reagents unless specified otherwise, were obtained from Merck (Darmstadt, FRG).

\section{Results}

\section{Precision}

Analytical precision was measured with dilutions of whole blood, stored at $-40^{\circ} \mathrm{C}$. The coefficient of variation of the duplicability and the day-to-day reproducibility were $3 \%$ and $7 \%$ respectively.

The precision of the iron determination in fixed liver tissue was assessed by measuring the iron content in two independently processed pieces of the same sample. The coefficient of variation of the duplicate values was calculated for the iron content measured in dried digested tissue, and for the iron content measured in native homogenate. We subsequently decided to measure iron in native homogenate, because this material gave a better precision $\left(\mathrm{CV}_{\text {duplo }}=13 \%\right.$ vs. $39 \%$ with acid digestion), and because this is also the method of choice for fresh (non fixed) liver tissue (6).

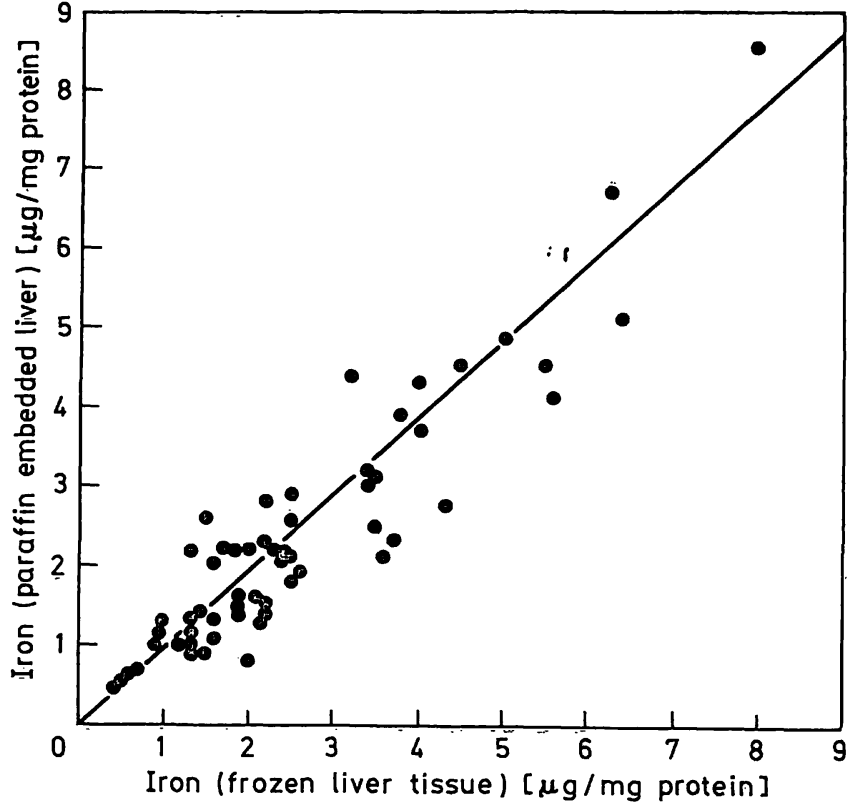

Fig. 1. Comparison of iron content ( $\mu \mathrm{g} / \mathrm{mg}$ protein) of frozen liver tissues (abscissa) vs. paraffin-embedded preparations (ordinate).

$\mathrm{y}=0.96 \mathrm{x}+0.03$

$\mathrm{r}=0.916 ; \mathrm{n}=58$

Correlation between the iron content in fresh and formaldehyde-fixed liver tissue

There was a good correlation between the iron determination in fresh and in fixed liver tissue, $r=0.92$, as shown in figure 1.

\section{Discussion}

The iron content in fixed liver tissue can be measured in acid-digested tissue and expressed per dry weight, or in liver homogenate and expressed per protein weight. The high $\mathrm{CV}_{\text {duplo }}(39 \%)$, which was found with the first method compared with the latter method $\left(\mathrm{CV}_{\text {duplo }}=13 \%\right)$ might be explained by incomplete removal of paraffin and practical difficulties (weighing, digesting) in processing very small samples $(<0.3$ $\mathrm{mg}$ ). For these reasons we decided to homogenize the liver tissue before the iron analysis.

The non-homogenized material was removed before the determination of iron and protein in order to prevent the inclusion of collageneous tissue (and vessel walls, bile ducts, fibrotic tissue) in the final preparation (6).

The coefficient of correlation between the total liver iron content in fresh tissue and paraffin-embedded, fixed tissue was 0.92 , and large differences between fresh and fixed tissue were not found (fig. 1). Hence it is possible to give an accurate estimation of the 
liver iron content in fixed tissue. This procedure can be advantageous for several reasons. Firstly, when iron loading is suspected after histochemical examination, a quantitative determination is possible with the same material. Secondly, material from the archives of pathological anatomical departments can be

\section{References}

1. Brissot, P., Bourel, M., Herry, D., Verger, J. P., Messner, M. Beaumont, C., Regnouard, F., Ferrand, B. \& Simon, $M$. (1981) Gastroenterology 80, 557-565.

2. van Eijk, H. G., Wiltink, W. F., Gre Bos \& Goossens, J. P. (1974) Clin. Chim. Acta 50, 275-280.

3. Barry, M. (1974) Gut $15,411-415$.

4. Searle, J. W., Kerr, J. F. R., Halliday, J. W. \& Powell, L. W. (1987) Iron stage disease. In: Pathology of the liver. 2nd edition (Mac Sween, R. N. M., Anthony, P. P. \& Scheuer, P. J., eds.) Churchill Livingstone, London, pp. 181-201. used for chemical iron determination even many years after the biopsy or autopsy. It can be mentioned, that only small amounts of material are required for a reliable protein determination, and the iron analysis with atomic absorption spectrophotometry is performed with micrograms of liver tissue.
5. Maharaj, B., Maharaj, R. J., Leary, W. P., Cooppan, R. M., Naran, A. D., Pirie, D. \& Pidifin, D. J. (1986) Lancet $I$, $523-525$.

6. van Deursen, C., de Metz, M., Koudstaal, J. \& Brombacher, P. (1988) J. Clin. Chem. Clin. Biochem. 26, 617-622.

7. Kreeftenberg, H. G., Koopman, B. J., Huizenga, J. R., van Vilsteren, T., Wolthers, B. G. \& Gips, C. H. (1984) Clin. Chim. Acta 144, 255-262.

8. Lowry, O. M., Rosebrough, N. J., Farr, A. L. \& Randall, R. J. (1951) J. Biol. Chem. 193, 265-275.

Prof. Dr. P. J. Brombacher

Department of Clinical Chemistry

De Wever-Ziekenhuis

P. O. Box 4446

NL 6401 CX Heerlen 
